\title{
PENERIMAAN PAJAK BUMI DAN BANGUNAN: ANALISIS KEBERHASILAN PADA KECAMATAN MEGAMENDUNG KABUPATEN BOGOR
}

\section{LAND AND BUILDING TAX REVENUE: THE SUCCESS ANALYSIS IN THE DISTRICT OF BOGOR DISTRICT MEGAMENDUNG}

\author{
Y.P. Hutomo, S. Marliani \\ Jurusan Akuntansi Fakultas Ekonomi Universitas Djuanda \\ Email: siti.marliani@unida.ac.id
}

\begin{abstract}
For four consecutive years, the target of the PBB provisions in the District of Bogor Regency Megamendung not always reach the target of the government's resolve, so that it becomes a topic of interest. This study was to determine the effect of the attitude of the taxpayer, the taxpayer awareness and knowledge of taxation to the success of tax revenue in the District of Bogor Regency Megamendung.This study design using a survey method that is associative causal population letter of tax payable (SPPT) is 24.821 WP, used as a sample of 400 respondents. The primary data collection method used is survey method with questionnaire media. Data analysis is the study used regression analysis techniques and different test t-test. Results of the analysis showed that simultaneous taxpayer attitudes, awareness of taxpayers and tax knowledge leads to successful tax revenue. Partially attitude of the taxpayer does not affect the success of PBB. Results of different test taxpayer civil servants (PNS) have significant differences with entrepreneurs, private employees and housewives (IRT).
\end{abstract}

Keywords: Attitude tax payer, the taxpayer awareness, knowledge of taxation and tax revenue success.

\begin{abstract}
ABSTRAK
Selama empat tahun berturut-turut, target ketetapan PBB pada Kecamatan Megamendung Kabupaten Bogor tidak selalu mencapai target ketetapan pemerintah, sehingga menjadi topik yang menarik. Penelitian ini untuk mengetahui pengaruh sikap wajib pajak, kesadaran wajib pajak dan pengetahuan perpajakan terhadap keberhasilan penerimaan PBB Pada Kecamatan Megamendung Kabupaten Bogor. Desain penelitian ini menggunakan metode survey yang bersifat asosiatif kausal dengan populasi surat pemberitauan pajak terutang (SPPT) PBB ialah 24.821 WP, sampel yang digunakan sebanyak 400 responden. Metode pengumpulan data primer yang digunakan ialah dengan metode survey dengan media kuisioner. Teknik analisis data yang dipakai penelitian merupakan teknik analisis regresi berganda dan uji beda t-test. Hasil analisis menunjukan bahwa secara simultan sikap wajib pajak, kesadaran wajib pajak dan pengetahuan perpajakan berpengaruh terhadap keberhasilan penerimaan PBB. Secara parsial sikap wajib pajak tidak berpengaruh terhadap keberhasilan penerimaan PBB. Hasil uji beda wajib pajak PNS memiliki perbedaan yang signifikan dengan wirausaha, karyawanswasta dan IRT.
\end{abstract}

Kata Kunci: Sikap wajib pajak, kesadaran wajib pajak, pengetahuan perpajakan dan keberhasilan penerimaan. 


\section{PENDAHULUAN}

Negara Indonesia mempunyai beragam jenis penerimaan pajak dikelola dan diterima oleh pemerintah. Beraneka macam pajak yang diterapkan terhadap masyarakat, salah satu dari sebagian diantaranya merupakan PBB. PPB ialah biaya atau pembayaran yang dibayarkan pertahun yang sudah menjadi WP Surat Pemberitauan Pajak Terutang (SPPT) yang mempunyai bangunan ataupun tanah kepada pemerintah. Mardiasmo (2016:1), pajak berlandaskan undang-undang nomor 6 tahun 1983 mengenai tata cara dan ketentuan umum perpajakan pada pasal 1 ayat 1 berbunyi pajak ialah kontribusi WP terhadap negara yang terutang bagi pribadi atau badan bersifat memaksa berlandaskan undang - undang tidak memperoleh kompensasi secara langsung, dipakai bagi keperluan negara yang berguna terhadap kemakmuran rakyat.

Sikap wajib pajak berpengaruh untuk pencapaian keberhasilan penerimaan, jika WP sudah memiliki pemikiran yang positif tentang PBB, sehingga tidak ada tunggakan $\mathrm{PBB}$ dalam setiap tahunnya dan target pencapaian penerimaan $\mathrm{PBB}$ akan tercapai yang ditetapkan pemerintah daerah. (Hardika:2006), sikap wajib pajak diartikan sebagai pertimbangan atau pernyataan evaluatif yang menguntungkan atau tidak perihal peristiwa, objek dan orang. WP kecil dan besar semuanya diperlakukan secara rata sehingga setiap WP cenderung untuk melaksanakan kewajibannya.

Kesadaran WP dalam penyetoran PBB secara tepat waktu sangat berguna untuk pencapaian target ketetapan penerimaan PBB. Dari kesadaran diri ketika penyetoran, sehingga tidak akan ada tunggakan PBB di tahun berikutnya ataupun ditahun sebelumnya dan target ketetapan pertahunnya akan selalu tercapai. Setiap WP harus memiliki kesadaran perpajakan dalam pembayaran $\mathrm{PBB}$, karna dari pencapaian penerimaan PBB berguna untuk pengembangan fasilitas daerah yang semakin baik. Irianto (2005:36), kesadaran perpajakan berkonsekuensi logis bagi WP agar mereka rela memberikan kontribusi dana untuk pelaksanaan fungsi perpajakan, dengan cara melaksanakan kewajiban pajakannya secara tepat waktu maupun tepat jumlah yang harus dibayarkan.

Pengetahuan perpajakan merupakan pemahaman, informasi yang diketahui atau dimengerti mengenai perpajakan. Sebagian wajib pajak mengetahui dari petugas pajak, televisi, radio, buku-buku pajak dan internet. Namun dalam penyampaian tentang pengetahuan perpajakan masih kurang, menimbulkan rendahnya WP ketika membayar yang mengakibatkan target ketetapan penerimaan PBB tidak selalu tercapai. Wiryawan (2012:299), pengetahuan pajak adalah informasi pajak yang dilakukan untuk bertindak, untuk menempuh strategi atau arah sehubungan mengenai hak dan kewajiban dibidang perpajakan dan pengambilan keputusan.

Berdasarkan Pasal 1 nomor 3 Undang-Undang nomor 4 tahun 2012 mengenai APBN tahun 2012, penerimaan pajak ialah seluruh penerimaan negara yaitu pajak perdagangan internasional dan dalam negeri. Penerimaan pajak dikatakan berhasil apabila tunggakan semakin menurun dan tingkat penerimaan mencapai pokok ketetapan. Keberhasilan pajak juga bisa dilihat kesediaan untuk membayar secara tepat waktu dan melunasi tunggakan pajaknya.

Surat Pemberitauan Pajak Terutang PBB dikirim oleh petugas desa kerumah rumah WP agar mempermudah dalam melakukan penyetoran. Untuk pembayaran PBB biasanya WP pembayarannya melalui Pak RT (rukun tetangga) melalui Bank BJB, Bank BRI bagian yang menangani penyetoran PBB. Berikut data yang menunjukan Ketetapan dan Realisasi Penerimaan PBB pada Kecamatan Megamendung Kabupaten Bogor periode 2013 - 2016 yang terlihat pada Tabel 1 . 
Tabel 1. Ketetapan dan Realisasi Penerimaan PBB pada Kecamatan Megamendung Kabupaten Bogor periode 2013 - 2016

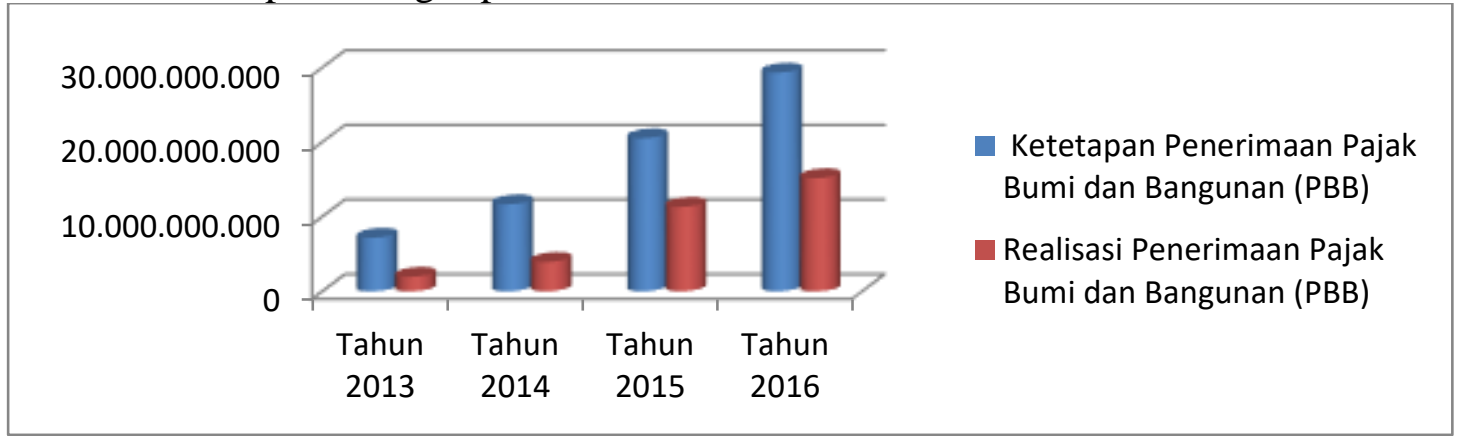

Sumber: UPT Pajak Daerah Ciawi, diolah 2017.

Tabel 1. menunjukan bahwa pertumbuhan dalam pencapaian penerimaan PBB. Mulai tahun 2013 menunjukan penerimaan terendah meskipun mulai tahun 2014 hingga tahun 2015 menunjukan kenaikan setiap tahunnya dalam ketetapan penerimaan PBB dan tahun 2016 terjadi penurunan presentase sejumlah 3,46\%. Di tahun 2013 menunjukan keberhasilan penerimaan yang sangat rendah, presentase target yang tercapai adalah 27,34\%. Tahun 2014 menunjukan kenaikan dalam keberhasilan penerimaan, presentase target yang tercapai adalah 33,83\%. Tahun 2015 menunjukan kenaikan keberhasilan penerimaan, presentase target yang tercapai adalah $55,25 \%$. Tahun 2016 mengalami penurunan keberhasilan penerimaan PBB, presentase target yang tercapai adalah 51,79\%. Karena masih kurangnya peran WP melaksanakan penyetoran, target ketetapan tidak selalu mencapai setiap tahunnya. Maka menjelaskan bahwa WP harus memiliki pengetahuan agar pemikiran WP menjadi positif sehingga meningkatkan keberhasilan penerimaan. Keaneka ragaman WP dari jenis pekerjaan dari wirausaha, PNS, IRT dan karyawanswasta apakah memiliki perbedaan.

\section{Tinjauan Teori}

Pengertian Pajak Bumi dan Bangunan

Muljono (2010:140), Pajak Bumi dan Bangunan adalah pajak kebendaan atas bumi atau bangunan dikenakan kepada subjek pajak. Hasil penerimaan PBB ialah pendapatan dibagi antara pemerintah pusat dan daerah.

\section{Surat Pemberitauan Pajak Terutang}

Mardiasmo (2016:382), Surat Pemberitauan Pajak Terutang (SPPT) adalah surat yang digunakan oleh Direktorat Jenderal Pajak yang memberitaukan besarnya pajak kepada wajib pajak.

\section{Pengertian Wajib Pajak (WP)}

Suandy (2008:107), wajib pajak ialah badan atau orang pribadi, meliputi pemungutan pajak dan pembayaran pajak, mempunyai kewajiban dan hak mengenai ketentuan peraturan perpajakan.

\section{Keberhasilan Penerimaan Perpajakan}

Mangkoesoebroto dan dkk (1994:22), faktor yang mempengaruhi keberhasilan perpajakan ialah tax payer, tax policy, tax law (Undang - Undang Perpajakan), dan tax administration. 


\section{Sikap Wajib Pajak}

Hardika (2006:77) sikap WP diartikan sebagai pertimbangan atau pernyataan evaluatif WP, yang tak menguntungkan atau menguntungkan mengenai peristiwa, orang atau objek.

\section{Kesadaran Wajib Pajak}

Mangkoesoebroto

(1994:52),

kesadaran wajib pajak sering dikaitkan dengan kerelaan dan kepatuhan mengenai kewajiban dan hak perpajakan sesuai peraturan yang berlaku.

\section{Pengetahuan Perpajakan}

Rahayu (2010:7), Pengetahuan pajak merupakan informasi pajak untuk bertindak, mempermudah dan pengambilan keputusan dibidang perpajakan. Berdasarkan pemahaman wajib pajak harus memiliki diantaranya adalah pengetahuan mengenai ketetapan tata cara perpajakan, sistem perpajakan dan fungsi perpajakan.

\section{Pengembangan Hipotesis}

Mangkoesoebroto dan dkk (1994:22), faktor yang mempengaruhi keberhasilan perpajakan ialah tax administration, tax payer. tax law dan tax policy.

Burton (2009:8), menyatakan keberhasilan penerimaan perpajakan (collection ratio) dipengaruhi oleh tax policy, tax administration, tax law, dan tax payer). Faktor yang melekat pada WP seperti denda PBB, pendapatan WP, kesadaran WP, pengetahuan WP tentang pelaksanaan sanksi.

hal ini diperkuat penelitian yang dilakukan oleh Rachman (2007) bahwa X2 berpengaruh terhadap Y. Fauziah (2008) bahwa X1 berpengaruh terhadap $\mathrm{Y}$. Setyawan (2011) bahwa X2 berpengaruh terhadap Y. Supriyati dan Kartika (2014) bahwa X1 dan X2 berpengaruh terhadap Y. Endrasari (2015) bahwa X2 berpengaruh terhadap Y dan Yanuesti (2015) bahwa X2 dan X3 berpengaruh terhadap Y.
$\mathrm{H}_{1} \quad$ :Diduga Sikap WP berpengaruh positif dan signifikan terhadap keberhasilan penerimaan PBB.

$\mathrm{H}_{2}$ :Diduga Kesadaran WP berpengaruh positif dan signifikan terhadap keberhasilan penerimaan PBB.

$\mathrm{H}_{3} \quad$ :Diduga Pengetahuan Perpajakan berpengaruh positif dan signifikan terhadap keberhasilan penerimaan PBB.

\section{Metode Penelitian}

Penelitian ini meneliti tentang pengaruh sikap WP, kesadaran WP dan pengetahuan perpajakan terhadap keberhasilan penerimaan PBB di Kecamatan Megamendung. Penelitian ini ialah penelitian kuantitatif. Dalam pelaksanaan penelitian ini akan digunakan bentuk penelitian verifikatif yang dilaksanakan melalui pengumpulan data dilapangan pada WP surat pemberitauan pajak terutang (SPPT) PBB.

\section{Variabel Penelitian dan Operasional Variabel}

Variabel independen (variabel bebas) penelitian ini ialah sikap wajib pajak, kesadaran wajib pajak dan pengetahuan perpajakan. Variabel dependen (variabel terikat) adalah keberhasilan penerimaan PBB. Adapun indikator dari keberhasilan penerimaan PBB, meliputi: pembagian hasil penerimaan, pembayaran PBB tepat waktu, layanan gratis dan pembangunan semakin baik.

Penelitian ini dua variabel, yaitu variabel bebas terdiri dari sikap WP (X1), kesadaran WP (X2) dan pengetahuan perpajakan (X3). Sedangkan variabel terikat yaitu keberhasilan penerimaan $\mathrm{PBB}$ (Y).

\section{Populasi, Sampel dan Teknik Pengambilan Sampel}

Populasi dalam penelitian ialah wajib Surat Pemberitauan Pajak Terutang 
(SPPT) PBB pada Kecamatan Megamendung Kabupaten Bog

Rumus yang dipakai dalam menentukan sampel yaitu menggunakan rumus slovin:

$$
n=\frac{\mathrm{N}}{\mathrm{N}(\mathrm{d})^{2}+1}
$$

Keterangan:

$\mathrm{n}=$ Sample

$\mathrm{N}=$ Populasi

$(d)=$ Nilai presisi $5 \%$ atau $(0,5)$

Berdasarkan rumus tersebut dapat ditentukan bahwa jumlah sampel yang dipakai ialah 400 WP, dengan jumlah populasi 24.821 WP SPPT PBB.

\section{Pengujian Instrumen}

Ghozali (2016:4), menyatakan skala likert adalah skala yang dijumlahkan (Summated Scale) yang pada dasarnya adalah ordinal. Pengolahan data ordinal menjadi analisis regresi ditransformasikan ke bentuk data interval dengan menggunakan rumus :

$$
\begin{gathered}
\text { Nilai Tertinggi }- \text { Nilai Terendah } \\
\text { Banyaknya Kelas } \\
=\frac{5-1}{5}=0,8
\end{gathered}
$$

Nilai yang dipakai setiap pernyataan adalah:

Tabel 2 Penilaian Kuisoner

\begin{tabular}{cc}
\hline Bobot Nilai & Jawaban Responden \\
\hline 1 & Sangat Tidak Setuju \\
2 & Tidak Setuju \\
3 & Kurang Setuju \\
4 & Setuju \\
5 & Sangat Setuju \\
\hline Sumber: Sugiyono $(2013: 137)$.
\end{tabular}

\section{Pengujian Validitas}

Ghozali (2016:52), menyatakan uji validitas digunakan untuk mengukur sah atau valid tidaknya suatu kuisoner.

$$
\begin{aligned}
& r_{\text {Hitung }} \\
& =\frac{n q\left(\sum x y\right)-\left(\sum x\right)\left(\sum y\right)}{\sqrt{\left\{n \sum x^{2}-\left(\sum x\right)^{2}\right\}\left\{n \sum y^{2}-\left(\sum y\right)^{2}\right\}}}
\end{aligned}
$$

Keterangan :

$r_{\text {Hitung }}=$ Koefisien validitas item yang dicari

$\mathrm{n}=$ Jumlah sampel

$\mathrm{x} \quad=$ Skor yang diperoleh dari

subyek dalam tiap item

$\mathrm{y} \quad=$ Skor total yang diperoleh dari subyek seluruh item

Tabel 3 Kriteria Uji Validitas

\begin{tabular}{cc}
\hline $\begin{array}{c}\text { Corrected Item Total } \\
\text { Corelation }\end{array}$ & Keterangan \\
\hline$\geq 0,3$ & Valid \\
$<0,3$ & Tidak Valid \\
\hline
\end{tabular}

Sumber:Sugiyono,2013.

\section{Pengujian Reliabilitas}

Ghozali (2016:47), menyatakan reabilitas sebenarnya adalah alat untuk mengukur suatu kuisoner yang merupakan indikator dari variabel atau konstruk.

Tabel 4 Kriteria Uji Reliabilitas

\begin{tabular}{cc}
\hline Alpha Cronbach & Keterangan \\
\hline$\geq 0,6$ & Reliabel \\
$<0,6$ & Tidak Reliabel \\
\hline
\end{tabular}

Sumber : Sugiyono, 2007.

\section{Uji Asumsi Klasik}

Sebelum melakukan pengujian hipotesis, terlebih dahulu dilakukan uji asumsi klasik yang mendasari penggunaan analisis regresi berganda. Asumsi-asumsi klasik tersebut menurut Ghozali (2016:103), adalah uji normalitas, uji multikolonieritas, uji autokorelasi dan uji heteroskedastisitas.

\section{Model Analisa Data}

Persamaan regresi berganda Sugiyono (2013:206), ialah berikut ini: 


$$
\mathrm{Y}=\alpha+\beta_{1} X_{1}+\beta_{2} X_{2}+\beta_{3} X_{3}+\varepsilon
$$

Dimana:

$Y \quad=$ Keberhasilan Penerimaan PBB

$\alpha \quad=$ Konstanta

$\beta_{1} \quad=$ Koefisien regresi

\section{Koefisien Determinasi}

Ghozali (2016:95), Analisis koefisien determinasi (Rsquare/ ${ }^{2}$ ) digunakan untuk mengetahui presentase sumbangan variabel Sikap WP, Kesadaran WP dan Pengetahuan Perpajakan terhadap Keberhasilan Penerimaan $\mathrm{PBB}$ berikut rumus:

$$
K D=r^{2} \times 100 \%
$$

\section{Uji Beda T-Test}

\section{Uji Beda Independen}

Ghozali (2016:64), Uji beda t-test ialah membandingkan perbedaan antara dua nilai rata-rata dengan standar error dari perbedaan rata-rata dua sample atau secara rumus sebagai berikut:

= Rata - rata sample pertama - rata - rata sample kedua Standar error perbedaan rata - rata kedua sample

\section{Uji Hipotesis}

\section{Uji Parsial (T-Test)}

Ghozali (2016:97), Uji dasarnya menunjukan seberapa jauh pengaruh satu variabel penjelas atau independen secara individual bagi menerangkan variasi variabel dependen. Langkah-langkah yang ditempuh dalam pengujian adalah sebagai berikut :

1. Menyusun Hipotesis Nol $\left(H_{0}\right)$ dan hipotesis alternatif $\left(H_{\mathrm{a}}\right)$

$$
\begin{aligned}
& \mathrm{H}_{\mathrm{o}}: \beta_{1}=0 \text {;Sikap WP tidak } \\
& \text { berpengaruh terhadap } \\
& \text { keberhasilan penerimaan } \\
& \mathrm{H}_{\mathrm{a}}: \beta_{1} \neq 0 \text {;Sikap WP berpengaruh } \\
& \text { terhadap keberhasilan } \\
& \text { penerimaan PBB. } \\
& \mathrm{H}_{\mathrm{o}}: \beta_{2}=0 \text {;Kesadaran WP } \\
& \text { tidak berpengaruh } \\
& \text { terhadap keberhasilan PBB. }
\end{aligned}
$$

$X_{1}=$ Koefesien regresi Sikap WP

$X_{2} \quad=$ Koefesien regresi Kesadaran

WP

$X_{3}=$ Koefesien regresi Pengetahuan Perpajakan

$\varepsilon \quad=$ Eror

$$
\begin{gathered}
\mathrm{H}_{\mathrm{a}}: \beta_{2} \neq 0 ; \quad \text { Kesadaran WP } \\
\text { berpengaruh terhadap } \\
\text { keberhasilan PBB. }
\end{gathered}
$$

$$
\begin{gathered}
\mathrm{H}_{\mathrm{o}}: \beta_{3}=0 ; \text { Pengetahuan } \\
\text { perpajakan tidak } \\
\text { berpengaruh terhadap } \\
\text { keberhasilan PBB. } \\
\mathrm{H}_{\mathrm{a}}: \beta_{3} \neq 0 ; \quad \text { Pengetahuan } \\
\text { Perpajakan } \\
\text { berpengaruh terhadap } \\
\text { keberhasilan PBB. }
\end{gathered}
$$

2. Kriteria Uji Hipotesisnya adalah :

a. Untuk Sikap WP bila thitung lebih kecil atau sama dengan $t_{\text {tabel }}\left(t_{\text {hitung }}\right.$ $\leq t_{\text {tabel }}$ ) pada $\alpha=0,05$ maka $\mathrm{H}_{\mathrm{o}}$ diterima dan $\mathrm{H}_{\mathrm{a}}$ ditolak.

b. Untuk Kesadaran WP bila thitung lebih kecil atau sama dengan $t_{\text {tabel }}$ (thitung $\leq t_{\text {tabel }}$ ) pada $\alpha=0,05$ maka $\mathrm{H}_{\mathrm{o}}$ diterima dan $\mathrm{H}_{\mathrm{a}}$ ditolak.

c. Untuk Pengetahuan Perpajakan bila $t_{\text {hitung }}$ lebih kecil atau sama dengan $\mathrm{t}_{\text {tabel }}\left(\mathrm{t}_{\text {hitung }} \leq \mathrm{t}_{\text {tabel }}\right)$ pada $\alpha$ $=0,05$ maka $\mathrm{H}_{\mathrm{o}}$ diterima dan $\mathrm{H}_{\mathrm{a}}$ ditolak.

\section{Uji Simultan $(f$-Test)}

1. Penentuan hipotesis, sebagai berikut: $\mathrm{H}_{\mathrm{o}}: \beta_{1}, \beta_{2}, \beta_{3}=0$; Sikap WP, Kesadaran WP dan

Pengetahuan Perpajakan tidak berpengaruh

secara simultan terhadap keberhasilan penerimaan PBB.

$$
\begin{array}{r}
\mathrm{H}_{\mathrm{a}}: \beta_{1}, \beta_{2}, \beta_{3} \neq 0 \text {; Sikap } \\
\text { Kesadaran } \quad \text { WP }
\end{array}
$$

Pengetahuan

Perpajakan berpengaruh secara simultan terhadap keberhasilan penerimaan PBB. 
2. Kriteria Keputusan Uji F

a. Jika $F_{\text {hitung }}$ lebih besar dari $\mathrm{F}_{\text {tabel }}$ ( $\left.F_{\text {hitung }}>F_{\text {tabel }}\right)$ dengan $\alpha=0,05$ maka $\mathrm{H}_{\mathrm{o}}$ ditolak dan Ha diterima.

b. Jika $F_{\text {hitung }}$ lebih kecil atau sama dengan $F_{\text {tabel }}\left(F_{\text {hitung }} \leq \mathrm{F}_{\text {tabel }}\right)$ dengan $\alpha=0,05$ maka Ho diterima dan Ha ditolak.

\section{HASIL DAN PEMBAHASAN}

Kabupaten Bogor ialah wilayah yang menjadi pusat kerajaan paling tua di Indonesia. Sejarah Dinasti Sung menulis di tahun 430, 433, 434, 437 dan 452 kerajaan Holotan adalah transliterasi Cina dari kata Aruteun, kerajaan Aruteun ialah kerajaan Hindu paling tua pada Pulau Jawa.

Secara administratif, Kecamatan Megamendung terdiri dari 12 Desa. 30 Dusun, 64 RW dan 276 RT. Jumlah penduduk berjumlah 95.184 jiwa, jumlah laki-laki 48.864 jiwa dan jumlah perempuan 46.320 jiwa. Serta 29.682 Kepala Keluarga (KK). Kecamatan Megamendung terdiri dari 12 desa. Rekaspitulasi karaskteristik responden yang telah dikelompokan dapat ditunjukan tabel 1.5 :

Tabel 5 Rekapitulasi Karakteristik Responden

\begin{tabular}{cclc}
\hline No & $\begin{array}{c}\text { Kriteria } \\
\text { Responden }\end{array}$ & Karakteristik & Jumlah/Orang \\
\hline 1. & Jenis & Laki-Laki & $216(54 \%)$ \\
& Kelamin & & Orang \\
2. & Pendidikan & SLTA & $239(60 \%)$ \\
3. & Jenis & Rata-rata & Orang \\
& Pekerjaan & adalah PNS & Wirausaha, \\
& & Karyawan- & \\
& & Swasta dan \\
& & IRT \\
\hline
\end{tabular}

Sumber: Data diolah 2017.

\section{Koefisien Determinasi}

Ghozali (2016:95), koefisien determinasi (R Square/ $R^{2}$ ) mengukur seberapa jauh kemampuan model dalam menerangkan variasi variabel dependen. Rumus yang digunakan:

$$
K D=r^{2} \times 100 \%
$$

Keterangan :

$$
\begin{array}{ll}
\mathrm{KD} & =\text { Koefisien Determinasi } \\
\mathrm{r} & =\text { Koefisien korelasi }
\end{array}
$$

Berdasarkan tabel 1.5 bahwa karakteristik responden dalam penelitian, didominasi oleh laki-laki sebanyak 216 orang $(54 \%)$, dengan pendidikan yang didominasi SLTA sebanyak 239 orang $(60 \%)$ dan rata-rata jenis pekerjaan didominasi oleh IRT, Karyawanswasta, Wiraswasta (Pengusaha dan Pedagang) dan PNS (pegawai (PNS) dan non pegawai (perangkat desa)). Berdasarkan karakteristik tersebut disimpulkan, wajib pajak di Kecamatan Megamendung rata rata latar belakang pendidikannya SLTA dan untuk jenis pekerjaan rata-rata didominasi PNS (PNS dan Perangkat Desa) Wiraswasta (Pengusaha dan Pedagang), Karyawanswasta dan IRT.

Berdasarkan rekapitulasi dari masingmasing jawaban responden, dibawah akan dijelaskan rekapitulasi dari keseluruhan tanggapan responden, pada Tabel 6:

Tabel 6 Rekapitulasi Tanggapan Responden

\begin{tabular}{cccc}
\hline No & Variabel & \multicolumn{2}{c}{$\begin{array}{c}\text { Nilai Rata- } \\
\text { Rata Skor } \\
\text { Tanggapan }\end{array}$} \\
\hline 1. & Sikap WP $\left(\mathrm{X}_{1}\right)$ & 4,28 & Sangat Setuju \\
2. & Kesadaran WP $\left(\mathrm{X}_{2}\right)$ & 4,17 & Setuju \\
3. & Pengetahuan & 4,04 & Setuju \\
& Perpajakan $\left(\mathrm{X}_{3}\right)$ & & Sangat Setuju \\
4. & & 4,21 & \\
\hline
\end{tabular}




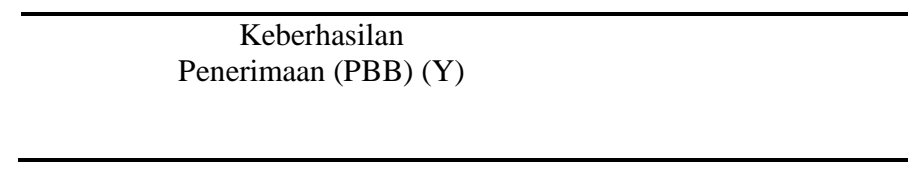

Sumber: Data diolah 2017

Berdasarkan tabel 1.6 tersebut, disimpulkan bahwa jawaban responden untuk variabel sikap WP yaitu memiliki nilai rata-rata skor tanggapan sebesar 4,28 dengan keterangan rata-rata sangat setuju dengan pernyataan kuesioner. Jawaban responden variabel kesadaran WP yaitu memiliki nilai rata-rata skor tanggapan sebesar $\quad 4,17$ dengan

penerimaan PBB yaitu memiliki nilai rata-rata skor tanggapan 4,21 dengan keterangan rata-rata sangat setuju dengan pernyataan kuisioner. Sehingga dapat disimpulkan, rata-rata responden setuju bahwa sikap WP, kesadaran WP dan pengetahuan perpajakan mempengaruhi keberhasilan penerimaan

\begin{abstract}
keterangan rata-rata setuju dengan pernyataan kuesioner. Jawaban responden untuk variabel pengetahuan perpajakan memiliki rata-rata skor tanggapan sebesar 4,04 dengan keterangan rata-rata setuju dengan pernyataan kuesioner. Selanjutnya jawaban responden untuk variabel keberhasilan
\end{abstract}

PBB di Kecamatan Megamendung.

\section{Pengujian Instrumen Uji Validitas}

Rekapitulasi dari rata-rata pengujian validitas terhadap semua pernyataan dalam masing-masing variabel tabel 1.7 :

Tabel 7 Rekapitulasi Uji Validitas

\begin{tabular}{llccc}
\hline \multicolumn{1}{c}{ No } & \multicolumn{1}{c}{ Variabel } & rhitung $_{\text {r }}$ & $\mathbf{r}_{\text {kritis }}$ & Keterangan \\
\hline 1. & Sikap WP (X1) & 0,373 & 0,3 & Valid \\
2. & Kesadaran WP (X2) & 0,492 & 0,3 & Valid \\
3. & Pengetahuan Perpajakan & 0,458 & 0,3 & Valid \\
& (X3) & & & Valid \\
4. & $\begin{array}{l}\text { Keberhasilan Penerimaan } \\
\text { PBB (Y) }\end{array}$ & 0,395 & 0,3 & \\
\hline
\end{tabular}

Sumber: Output pengelolaan data dengan SPSS 20, diolah 2017.

Berdasarkan tabel 1.7 keberhasilan penerimaan PBB sebesar menunjukan bahwa dilihat dari skor rata- $\quad 0,395$ semuanya menunjukan nilai hitung rata variabel sikap WP yaitu sebesar yang lebih dari 0,3 sehingga dapat 0,373, variabel kesadaran WP bernilai dinyatakan bahwa semua instrumen yang 0,492 , variabel pengetahuan perpajakan digunakan valid, dan layak digunakan. sebesar 0,458, dan

\section{Uji Reliabilitas}

Rekapitulasi dari rata-rata uji reliabilitas ialah tabel 1.8:

Tabel 8 Rekapitulasi Uji Reliabilitas 


\begin{tabular}{clccc}
\hline No Pernyataan & \multicolumn{1}{c}{ Variabel } & $\begin{array}{c}\text { Cronbach's Alpha } \\
\text { Item-Total } \\
\text { Correlation }\end{array}$ & Rkritis & Kesimpulan \\
\hline 1. & Sikap WP (X1) & 0,784 & 0,6 & Reliabel \\
2. & Kesadaran WP (X2) & 0,776 & 0,6 & Reliabel \\
3. & Pengetahaun & 0,777 & 0,6 & Reliabel \\
& Perpajakan (X3) & 0,782 & 0,6 & Reliabel \\
& Keberhasilan & & & \\
\hline
\end{tabular}

Sumber: Output pengelolaan data dengan SPSS 20, diolah 2017.

Berdasarkan tabel 1.8 tersebut, rekapitulasi uji reliabilitas dari setiap rata-rata item pernyataan variabel sikap WP sejumlah 0,784, kesadaran WP sebesar 0,776 , pengetahuan perpajakan bernilai

\section{Hasil dan Pembahasan}

Sugiyono (2013:206), menyatakan bahwa teknik regresi linier berganda (multiple regression analysis) digunakan untuk mengetahui hubungan fungsional dinaikan atau diturunkan nilainya. Hasil pada tabel 9 dibawah ini:

Tabel 9 Analisis Regresi Linear Berganda

\begin{tabular}{|c|c|c|c|c|c|c|}
\hline \multirow[t]{2}{*}{ Model } & & \multicolumn{2}{|c|}{$\begin{array}{l}\text { Unstandardized } \\
\text { Coefficients }\end{array}$} & \multirow{2}{*}{$\begin{array}{c}\text { Standardized } \\
\text { Coefficients }\end{array}$} & \multirow[t]{2}{*}{$\mathbf{T}$} & \multirow[t]{2}{*}{ Sig } \\
\hline & & B & Std. Error & & & \\
\hline \multirow{4}{*}{1} & (Constant) & 7,935 & 1,132 & & 7,009 & ,000 \\
\hline & $\begin{array}{l}\text { Sikap Wajib } \\
\text { Pajak }\end{array}$ & 039 & ,035 & ,056 & 1,109 & 268 \\
\hline & $\begin{array}{l}\text { Kesadaran } \\
\text { Wajib Pajak }\end{array}$ & 219 & ,044 & 269 & 5,012 & ,000 \\
\hline & $\begin{array}{l}\text { Pengetahuan } \\
\text { Perpajakan }\end{array}$ & ,267 & ,043 & 303 & 6,188 & ,000 \\
\hline
\end{tabular}

a.Dependent Variable: Keberhasilaan Penerimaasn PBBs

Sumber: Output pesngolahan dasta dengasn SPSSz 20, 2017

Berdasarkan tabel 1.9 diketahui bahwa nilai dari persamaan regresi yaitu sebagai berikut:

$$
\gamma=a+\beta_{1} X_{1}+\beta_{2} X_{2}+\beta_{3} X_{3}+\varepsilon
$$

$\gamma=7,935+0,039 X_{1}+0,219 X_{2}$

$$
+0,267 X_{3}+\varepsilon
$$

Interpretasi regresi tersebut ialah:

1. Hasil persamaan regresi tersebut diperoleh nilai konstanta sebesar 7,935 nilai tersebut mempunyai arti bahwa jika semua variabel bebas yaitu sikap WP, kesadaran WP dan pengetahuan
0,777 dan keberhasilan penerimaan PBB sebesar 0,782, semua nilai tersebut menunjukan lebih besar dari 0,6 sehingga semua instrumen yang digunakan dapat dikatakan reliabel, dan layak digunakan.

antara beberapa variabel bebas terhadap variabel terikat, untuk meramalkan bagaimana perubahan nilai variabel dependen, bila nilai variabel independe 
keberhasilan penerimaan PBB sebesar 0,039.

3. Hasil persamaan regresi untuk variabel kesadaran WP bernilai 0,219 . Untuk setiap peningkatan kesadaran WP bernilai satu satuan, dengan asumsi variabel sikap WP dan pengetahuan perpajakan bernilai 0,maka menyebabkan meningkatnya keberhasilan penerimaan PBB sebesar 0,219.
4. Hasil persamaan regresi untuk variabel pengetahuan perpajakan sebesar 0,267. Untuk setiap peningkatan pengetahuan perpajakan sebesar satu satuan, dengan asumsi variabel sikap WP dan kesadaran WP bernilai 0 , maka menyebabkan meningkatnya keberhasilan penerimaan PBBsebesar 0,267.

\section{Pengujian Hipotesis}

Tabel 10 Koefisien Determinasi

Model Summaryb

\begin{tabular}{lcccc}
\hline Model & $\mathbf{R}$ & R Square & $\begin{array}{c}\text { Adjusted } R \\
\text { Square }\end{array}$ & $\begin{array}{c}\text { Std. Error of the } \\
\text { Estimate }\end{array}$ \\
\hline 1 &, 521 &, 272 &, 266 &, 942
\end{tabular}

Sumber: Output pengolahan data dengan SPSS 20, 2017.

Berdasarkan tabel 1.10, diperoleh $\mathrm{R}^{2}$ (R square) sebesar 0,272 atau $(27,2 \%)$. menjelaskan bahwa kontribusi sikap WP, kesadaran WP dan pengetahuan perpajakan terhadap keberhasilan penerimaan PBB sebesar 27,2\%, sedangkan sisanya $72,8 \%$ dipengaruhi atau dijelaskan oleh variabel lain yang tidak dimasukan dalam model penelitian ini seperti denda $\mathrm{PBB}$, pengetahuan WP, pendapatan WP, tax policy, dan tax administration.

\section{Uji Beda T-Test}

\section{Uji Beda Independen}

1. Uji Beda Sikap Wajib Pajak Responden PNS dan Wirausaha Hasil pengujian dengan menggunakan Independen sampel test bahwa $\mathrm{F}$ hitung levene test sebesar 3,735 dengan probabilitas 0,055 karena probabilitas > 0,05 maka $\mathrm{HO}$ tidak dapat ditolak atau memiliki variance yang sama. Dengan demikian analisis uji beda t-test harus menggunakan asumsi equal variance assumed adalah 4,753 dengan probabilitas signifikan 0,000 (two tail). Disimpulkan bahwa rata-rata sikap wajib pajak berbeda secara signifikan antara responden PNS (pegawai (PNS) dan non pegawai (perangkat desa)) dan wirausaha (pengusaha dan pedagang).

2. Uji Beda Sikap Wajib Pajak Responden Karyawanswasta dan IRT Hasil pengujian dengan menggunakan Independen sampel test bahwa $\mathrm{F}$ hitung levene test sebesar 0,008 dengan probabilitas 0,930 karena probabilitas > 0,05 maka $\mathrm{H} 0$ tidak dapat ditolak atau memiliki variance yang sama. Dengan demikian analisis uji beda t-test harus menggunakan asumsi equal variance assumed adalah 1,042 dengan probabilitas signifikan 0,299 (two tail). Disimpulkan bahwa rata-rata sikap wajib pajak berbeda tetapi tidak signifikan antara responden karyawanswasta dan IRT.

3. Uji Beda Kesadaran Wajib Pajak Responden PNS dan Wirausaha Hasil pengujian dengan menggunakan Independen sampel test bahwa $\mathrm{F}$ hitung levene test sebesar 78,149 
dengan probabilitas 0,000 karena probabilitas < 0,05 maka $\mathrm{H} 0$ ditolak atau memiliki variance berbeda. Dengan demikian analisis uji beda ttest harus menggunakan asumsi equal variance assumed adalah 3,814 dengan probabilitas signifikan 0,000 (two tail). Disimpulkan bahwa ratarata kesadaran WP berbeda secara signifikan antara responden PNS (pegawai (PNS) dan non pegawai (perangkat desa)) dan wirausaha (pengusaha dan pedagang).

4. Uji Beda Kesadaran Wajib Pajak Responden Karyawanswasta dan IRT

Hasil pengujian dengan menggunakan Independen sampel test bahwa $\mathrm{F}$ hitung levene test sebesar 1,748 dengan probabilitas 0,188 karena probabilitas > 0,05 maka H0 tidak dapat ditolak atau

pengetahuan perpajakan berbeda secara signifikan antara responden PNS (pegawai (PNS) dan non pegawai (perangkat desa)) dan wirausaha (pengusaha dan pedagang).

6. Uji Beda Pengetahuan Perpajakan Responden Karyawanswasta dan IRT

Hasil pengujian dengan menggunakan Independen sampel test bahwa $\mathrm{F}$ hitung levene test sebesar 96,989 dengan probabilitas 0,000 karena probabilitas $<0,05$ maka $\mathrm{H} 0$ ditolak atau memiliki variance yang berbeda. Dengan demikian analisis uji beda t-test harus menggunakan asumsi equal variance assumed adalah 2,795 dengan probabilitas signifikan 0,006 (two tail). Disimpulkan bahwa ratarata pengetahuan perpajakan berbeda tetapi tidak signifikan antara responden karyawanswasta dan IRT. memiliki variance yang sama. Dengan demikian analisis uji beda ttest harus menggunakan asumsi equal variance assumed adalah 2,971 dengan probabilitas signifikan 0,003 (two tail). Disimpulkan bahwa rata-rata kesadaran WP berbeda secara signifikan antara responden karyawanswasta dan IRT.

5. Uji Beda Pengetahuan Perpajakan Responden PNS dan Wirausaha Hasil pengujian dengan menggunakan Independen sampel test bahwa $\mathrm{F}$ hitung levene test sebesar 131,507 dengan probabilitas 0,00 karena probabilitas < 0,05 maka $\mathrm{H} 0$ ditolak atau memiliki variance yang berbeda. Dengan demikian analisis uji beda ttest harus menggunakan asumsi equal variance assumed adalah 6,248 dengan probabilitas signifikan 0,00 (two tail). Disimpulkan bahwa ratarata

7. Uji Beda Keberhasilan Penerimaan PBB Responden PNS dan Wirausaha Hasil pengujian dengan menggunakan Independen sampel test bahwa $\mathrm{F}$ hitung levene test sebesar 20,597 dengan probabilitas 0,000 karena probabilitas < 0,05 maka H0 ditolak atau memiliki

variance yang berbeda. Dengan demikian analisis uji beda t-test harus menggunakan asumsi equal variance assumed adalah 5,539 dengan probabilitas signifikan 0,000 (two tail). Disimpulkan bahwa rata-rata keberhasilan penerimaan PBB berbeda secara signifikan antara responden PNS (pegawai (PNS) dan non pegawai (perangkat desa)) dan wirausaha (pengusaha dan pedagang).

8. Uji Beda Keberhasilan Penerimaan PBB Responden Karyawanswasta dan IRT Hasil pengujian dengan menggunakan Independen sampel test bahwa $\mathrm{F}$ hitung levene test sebesar 
0,075 dengan probabilitas 0,785 karena probabilitas > 0,05 maka $\mathrm{H} 0$ tidak dapat ditolak atau memiliki variance yang sama. Dengan demikian analisis uji beda t-test harus menggunakan asumsi equal variance assumed adalah 1,890 dengan probabilitas signifikan 0,060 (two tail). Disimpulkan bahwa rata-rata keberhasilan penerimaan PBB berbeda tetapi tidak signifikan antara responden karyawanswasta dan IRT.

\section{UJI F}

Hasil uji F dapat diperoleh melalui tabel analisis varians (Anova) terlihat pada tabel 1.11 dibawah ini:

Tabel 1.1 Uji F

ANOVA $^{\mathrm{a}}$

\begin{tabular}{lllllll}
\hline Model & & $\begin{array}{c}\text { Sum Of } \\
\text { Squares }\end{array}$ & Df & $\begin{array}{l}\text { Mean } \\
\text { Square }\end{array}$ & F & Sig \\
\hline 1 & Regression & 131,158 & 3 & 43,719 & 49,307 &, $000^{\mathrm{b}}$ \\
& Residual & 351,120 & 396 &, 887 & & \\
& Total & 482,278 & 399 & & & \\
& & & & & & \\
\hline
\end{tabular}

a.Dependent Variabel: Keberhasilan Penerimaan PBB

b.Predictors: (Constant), Sikap WP,Kesadaran WP dan pengetahuan perpajakan

Sumber: Output pengolahan data dengan SPSS 20, 2017.

Berdasarkan tabel 1.11 tersebut dapat diketahui bahwa hasil pengujian menggunakan uji $\mathrm{F}$, diperoleh nilai $\mathrm{F}_{\text {hitung }}$ sebesar 49,307, sedangkan nilai $\mathrm{F}_{\text {tabel }}$ sebesar 2,62. Apabila F Fitung dibandingkan

Kesadaran Wajib Pajak dan Pengetahuan Perpajakan secara simultan berpengaruh signifikan terhadap Keberhasilan

Uji T

Hasil output SPSS untuk uji t dapat pada tabel 1.12 berikut ini :

Tabel $1.12 \mathrm{Uji}$ T

Coefficients $^{\mathrm{a}}$

\begin{tabular}{|c|c|c|c|c|c|c|}
\hline \multirow[t]{2}{*}{ Model } & & \multicolumn{2}{|c|}{$\begin{array}{l}\text { Unstandardized } \\
\text { Coefficients }\end{array}$} & \multirow{2}{*}{$\begin{array}{l}\text { Standardized } \\
\text { Coefficients } \\
\text { Beta }\end{array}$} & \multirow[t]{2}{*}{$\mathbf{T}$} & \multirow[t]{2}{*}{ Sig } \\
\hline & & B & Std. Error & & & \\
\hline \multirow{4}{*}{1} & (Constant) & 7,935 & 1,132 & & 7,009 & ,000 \\
\hline & Sikap WP & ,039 & ,035 & ,056 & 1,109 & 268 \\
\hline & $\begin{array}{l}\text { Kesadaran } \\
\text { WP }\end{array}$ & 219 & ,044 & 269 & 5,012 & ,000 \\
\hline & $\begin{array}{l}\text { Pengetahuan } \\
\text { Perpajakan }\end{array}$ & 267 & ,043 & 303 & 6,188 & 000 \\
\hline
\end{tabular}

a.Dependent Variabel: Keberhasilan Penerimaan PBB

Sumber: Output pengolahan data dengan SPSS 20, 2017

Sikap Wajib Pajak

Hasil pengujian uji $\mathrm{t}$ diperoleh nilai thitung untuk Sikap WP bernilai 1,109, 
sedangkan nilai $t_{\text {tabel }}$ sebesar 1,965 . Apabila $t_{\text {hitung }}$ dibandingkan dengan $t_{\text {tabel }}$ maka $t_{\text {hitung }}<\mathrm{t}_{\text {tabel }}(1,109<1,965)$ dengan tingkat signifikan sebesar $0,268>0,005$. Hal ini menjelaskan bahwa $\mathrm{H}_{\mathrm{o}}$ diterima dan $\mathrm{H}_{\mathrm{a}}$ ditolak. Kondisi ini bermakna Sikap WP secara parsial tidak berpengaruh terhadap keberhasilan penerimaan PBB pada Kecamatan Megamendung.

\section{Kesadaran Wajib Pajak}

Hasil pengujian uji t diperoleh nilai thitung untuk Kesadaran WP sebesar 5,012, sedangkan nilai $t_{\text {tabel }}$ bernilai 1,965. Apabila $t_{\text {hitung }}$ dibandingkan dengan $t_{\text {tabel }}$ maka $t_{\text {hitung }}>t_{\text {tabel }}(5,012>$ 1,965) dengan tingkat signifikan sebesar $0,000<0,005$. Hal ini menjelaskan bahwa $\mathrm{H}_{\mathrm{o}}$ ditolak dan $\mathrm{H}_{\mathrm{a}}$ diterima. Kondisi ini bermakna Kesadaran WP secara parsial berpengaruh terhadap keberhasilan penerimaan PBB pada Kecamatan Megamendung.

\section{Pengetahuan Perpajakan}

Hasil pengujian uji $\mathrm{t}$ diperoleh nilai $t_{\text {hitung }}$ untuk Pengetahuan Perpajakan sebesar 6,188, sedangkan nilai $t_{\text {tabel }}$ sebesar 1,965. Apabila $t_{\text {hitung }}$ dibandingkan dengan $t_{\text {tabel }}$ maka $t_{\text {hitung }}>$

Kesadaran Wajib Pajak PNS dan Wirausaha berbeda secara signifikan, Kesadaran Wajib Pajak Karyawanswasta dan IRT berbeda secara signifikan. Pengetahuan Perpajakan PNS dan Wirausaha berbeda secara signifikan, Pengetahuan Karyawanswasta dan IRT berbeda tetapi tidak signifikan dan Keberhasilan Penerimaan PBB PNS dan Wirausaha berbeda secara signifikan, Keberhasilan Penerimaan PBB Karyawanswasta dan IRT berbeda tetapi tidak signifikan.

\section{DAFTAR PUSTAKA}

Endrasari dan dkk, 2015, Pengaruh Pemahaman, Kesadaran, $t_{\text {tabel }}(6,188>1,965)$ dengan tingkat signifikan sebesar $0,000<0,005$. Hal ini menjelaskan $\mathrm{H}_{\mathrm{o}}$ ditolak dan $\mathrm{H}_{\mathrm{a}}$ diterima. Kondisi ini bermakna bahwa Pengetahuan Perpajakan secara parsial berpengaruh terhadap keberhasilan penerimaan PBB pada Kecamatan Megamendung.

\section{Kesimpulan}

1. Terdapat pengaruh sikap wajib pajak, kesadaran wajib pajak dan pengetahuan perpajakan secara simultan terhadap keberhasilan penerimaan PBB pada Kecamatan Megamendung Kabupaten Bogor.

2. a. Tidak terdapat pengaruh sikap wajib pajak seacara parsial terhadap keberhasilan penerimaan PBB.

b. Terdapat pengaruh kesadaran wajib pajak dan pengetahuan perpajakan secara parsial terhadap keberhasilan penerimaan PBB.

3. Terdapat perbedaan jenis pekerjaan dari wajib pajak dilihat dari Sikap Wajib Pajak PNS dan Wirausaha berbeda secara signifikan, Sikap Wajib Pajak Karyawanswasta dan IRT berbeda tetapi tidak signifikan.

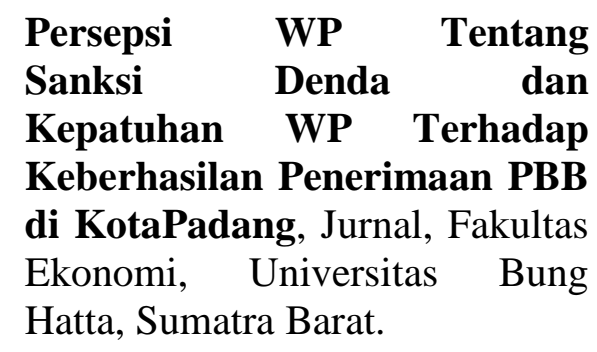

Fauziyah, Laily, 2008, Pengaruh

Karakteristik Pada WP

Terhadap Keberhasilan

PBBPada Kantor Pelayanan

PBB Jakarta Selatan Satu,

Skripsi, Universitas Islam

Negeri Syarif Hidayatulah, Jakarta.

Hardika, N, Sentosa, 2006, Pengaruh Lingkungan dan Moral WP Terhadap Sikap dan 
Kepatuhan Wajib Pajak Pada Hotel Berbintang di

Propinsi Bali, Skripsi,

Universitas Airlangga, Surabaya.

Irianto, slamet, edi, 2005, Politik

Perpajakan Membangun

Demokrasi Negara, UII Press,

Yogyakarta.

Ghozali, Imam, 2016, Aplikasi Analisis

Multivariate dengan Prograqm

SPSS, Edisi Kedelapan, Badan

Penerbit Universitas Diponogoro,

Semarang.

Mangkoesoebroto, Guritno dan dkk,

1994, Kebijakan Ekonomi

Publik di Indonesia Substansi

dan Urgensi，PT. Gramedia

Pustaka Utama, Jakarta.

Mardiasmo, 2016, Perpajakan, Edisi

terbaru, C.V Andi Offset,

Yogyakarta.

Muljono, Djoko, 2010, Panduan Brevet

Pajak, C.V Andi Offset, Yogyakarta.

Rachman, Arif, 2007, Pengaruh

Pemahaman, Kesadaran, Serta

Kepatuhan WP Bumi dan

Bangunan Terhadap

Keberhasilan PBB di

Kecamatan Kota Sumenep

Kabupaten Sumenep, Jurnal,

Universitas Trunojoyo,

Madura.

Mempengaruhi Keberhasilan

Penerimaan PBB (Studi Kasus

Pada Semarang Tengah),

Jurnal, Universitas Stikubank.

Wirawan, Ilyas, 2012, Perpajakan,

Mitra Wacana Media, Jakarta.

Wulandari, Ika, 2010, Analisis

Faktor- Faktor Yang

Mempengaru

Keberhasilan PBB (Studi Kasus

di Kelurahan

SelosariKecamatan Magetan),

Skripsi,

Universitas

Pembangunan Nasional

"Veteran" Jawa Timur.
Rahayu, Kurnia, Siti, 2010, Perpajakan

Indonesia, Graha Ilmu,

Yogyakarta.

Riduwan, 2005, Belajar Mudah

Penelitian Untuk Guru,

Karyawan dan Peniliti

Pemula, Alfabeta, Bandung.

Republik Indonesia Pasal 1 angka 3

Undang- Undang nomor.4

tahun 2012 yang diundangkan

oleh Menteri Sekretaris Negara

Republik Indonesia

mengenai Anggaran

Pendapatan dan Belanja

Negara (APBN).

Setyawan, Haris, M, 2011, Analisis

Faktor- Faktor Yang

Mempengaruhi Penerimaan

PBB (Studi di

Kelurahan Pulorejo

Mojokerto), Skripsi,

Universitas Pembangunan

Nasional "Veteran" Jawa Timur.

Suandy, Erly, 2008, Hukum Pajak, Edisi

Empat, Salemba Empat,

Jakarta.Sugiyono, 2013, Metode

Penelitian Kombinasi, Alfabeta,

Bandung.

Sugiyono, 2007, Metodologi Penelitian

Administrasi, Alfabeta, Bandung.

Supriyati dan Kartika, 2014, Analisis

Faktor - Faktor Yang

Yanuesti dan dkk, 2015, Pengaruh Pengetahuan, Kesadaran, dan Kepuasan WP Terhadap Keberhasilan Penerimaan PBB Pedesaan/Perkotaan di Kecamatan Talun Kabupaten Blitar, Jurnal, Universitas Brawijaya, Jawa Timur. 